\title{
Application of molecular methods in weed science
}

\author{
Dragana Božić, Markola Saulić, Sava Vrbničanin
}

\begin{abstract}
Molecular methods are useful tools for weed science, especially in the area of weed resistance to herbicides and gene flow from herbicide tolerant crops to their wild relatives. Also, genetic variability plays an important role in weed susceptibility to herbicides and affect on strategies of control. For all of these studies, DNA, as a starting material, could be extracted by various methods; though, the easiest and the most suitable is extraction by using commercially available kits. The most important part of molecular analysis is selection and design of adequate primers for successful DNA amplification. Usually, primer selection and designing are based on DNA sequences stored in GenBank. Analysis following selected DNA fragments will depend on type of research. For weed resistance or gene flow studies, amplified fragments are sequenced and obtained information compared with the GenBank sequence database, with the aim to check for mutation(s) presence. For genetic diversity of weed species analysis of amplified DNA fragments include Capillary Electrophoresis.
\end{abstract}

\section{How to cite this book chapter:}

Božić, D., Saulić, M. and Vrbničanin, S. 2019. Application of molecular methods in weed science. In: Vucelić Radović, B., Lazić, D. and Nikšić, M. (eds.) Application of Molecular Methods and Raman Microscopy/Spectroscopy in Agricultural Sciences and Food Technology, Pp. 15-22. London: Ubiquity Press. DOI: https://doi.org/10.5334/ bbj.b. License: CC-BY 4.0 


\section{Introduction}

Molecular methods can be useful for different weed science research topics including molecular determination of weed species which is difficult for determination based on non- molecular methods, population variability, weed resistance to herbicides and gene flow between herbicide-tolerant crops and their wild relatives.

Over the last period weed resistance to herbicides has become an increasing problem (Moss et al. 2007; Michitte et al. 2007). In most cases, evolved weed resistance is due to mutation/mutations within gene encoding enzymes which represent herbicide target site. Therefore, it is possible to use a variety of molecular-based assays that are much faster and less labor intensive than traditional methods (e.g. whole-plant bioassay). Detecting weed resistance to herbicides using DNA based techniques is a very important mission, especially with increasing use of newly-bred herbicide- tolerant crops. There are potential risks associated with growing these crops such as gene flow from herbicidetolerant crops to non-tolerant crops, or to wild relatives, or volunteer crops. This leads to incidences of resistant species (weeds) (Martinez-Ghersa et al. 1997). Molecular markers have proven valuable in determining the frequency of crop-weed hybridization.

Molecular-based approaches have been used in a variety of ways to explore the genetic diversity of weeds. Studies of genetic diversity can be used for determination of species center of origin (Goolsby et al. 2006, Madeira et al. 2007). Such knowledge can be used to direct searches for potential biological control agents (Paterson et al. 2009). Other genetic diversity studies have been conducted with vegetative propagated perennial weed species, with a goal to determine the relative role of sexual versus vegetative reproduction to the success of the weeds (Slotta et al. 2006). Also, studies of genetic diversity in weed populations can be extremely important because they provide essential background for their different susceptibility to herbicides.

\section{Materials, Methods and Notes}

\subsection{Assessment of gene flow from herbicide tolerant sunflower to weedy sunflower by end-point PCR}

End-point PCR is suitable for detection mutations responsible for weed resistance to herbicides and confirmation gene flow from tolerant crops to weedy relatives. Namely, the alteration of ALS (acetolactate synthase) gene by one of many possible point mutations is main mechanism of weed resistance to ALSinhibiting herbicides, which represent group of herbicides to which weeds usually developed resistance. There are eight possible point mutations detected until now in different weed species. As position of potential mutation is known, 
their detection is based on amplification of the appropriate DNA fragment, using specific primers. After amplification PCR products have to be sequencing and check presence of mutation in obtained sequences.

\subsubsection{Plant material}

Seed material for weed resistance to herbicides research should be is collect in the fields for which there are indications about resistance development. Also, it is necessary to collect seeds of the same species from the areas where there is no herbicide application history. For gene flow studies, it is possible to establish field experiment which includes different variants of crop-wild relative distance or to collect seeds from wild relatives of crop (in our case weedy sunflower seeds) from the tolerant crop growing area. Young plants produced from collected seeds are sampled and some leaf samples (taken from a single plant) were used for DNA extraction immediately after sampling, while some of them stored in a freezer $\left(-20^{\circ} \mathrm{C}\right)$ until analysis. Before analysis samples were lyophilized after storage at the $-80^{\circ} \mathrm{C}$ during $24 \mathrm{~h}$.

\subsubsection{DNA extraction}

DNA extraction was done using the QiagenDneasy ${ }^{\oplus}$ Plant Mini Kit following the manufacturer's protocol (https://www.qiagen.com/dz/shop/sampletechnologies/dna/dna-preparation/dneasy-plant-mini-kit/). The quality and concentration of extracted DNA were determined spectrophotometrically using a Nanodrop ${ }^{\oplus} 1000$. DNA extracts were stored at $-20^{\circ} \mathrm{C}$ when not in use.

Note: The samples were grinded to a fine powder either using a mortar and pestle or TissueLyser. The lyophilized samples were grinded successfully with both methods, but TissueLyser was not a good choice for fresh samples. Instead of getting a fine powder, the TissuLyser was turning fresh material into squashy product.

\subsubsection{Primers selection}

DNA sequences from several sources were used to design oligonucleotide primers for amplifying ALS gene fragments (White et al., 2003, Kolkman et al., 2004). Two primers were designed using the software Primer 3. The primers Hel ForA (CAATGGAGATCCACCAAGCT) and Hel RevA (AACGCAAGCAACAAATCACT) used for amplification approximately 700bp fragments.

Note: In the literature, there are plenty of primers, which can be used to detect mutations responsible for resistance/tolerance of different sunflower forms to herbicides. Based on their analysis and comparison, and analysis of sequences of DNA fragments from sunflower stored at the GenBank new primers were designed. 


\subsubsection{Amplification of specific region of the ALS gene}

Final PCR reaction condition were: $19 \mu \mathrm{l}$ of mastermix (10 units Biomix, 7 units DEPC water, 1 unit forward primer and 1 unit reverse primer) and $1 \mu$ of DNA sample. Cycling conditions were: 2 min incubation at $94^{\circ} \mathrm{C}$; 35 cycles of $30 \mathrm{sec}$ denaturation at $94^{\circ} \mathrm{C}, 20 \mathrm{sec}$ annealing at $53^{\circ} \mathrm{C}$ and $45 \mathrm{sec}$ extension at $72^{\circ} \mathrm{C}$; and $5 \mathrm{~min}$ final extension at $72^{\circ} \mathrm{C}$. PCR products were electrophoresed on $2 \%$ low-melt agarose gel containing ethidium bromide.

Note: Amplification of DNA fragments was successful while using Biomix, purchased from one manufacturer. Switching to other manufacturer of Biomix failed to generate any PCR products. Initially, we didn't realize what was causing the problem and spent significant time and materials, checking other components of PCR reaction and optimizing the assay itself, but without success. Finally, when we changed Biomix again, and chose the one that had been initially used, the amplification became successful again.

\subsubsection{Sequencing}

PCR products purification was done before sequencing using the Spin Column PCR Purification Kit following the manufacturer's protocol (http://www.nbsbio. co.uk/downloads/DNA_Cleanup_Handbook.pdf). Purified products were sent together with the corresponding primer (Hel ForA) to Sorce Bioscience (Osford, UK) for sequencing. Analysis of obtained sequences were done based

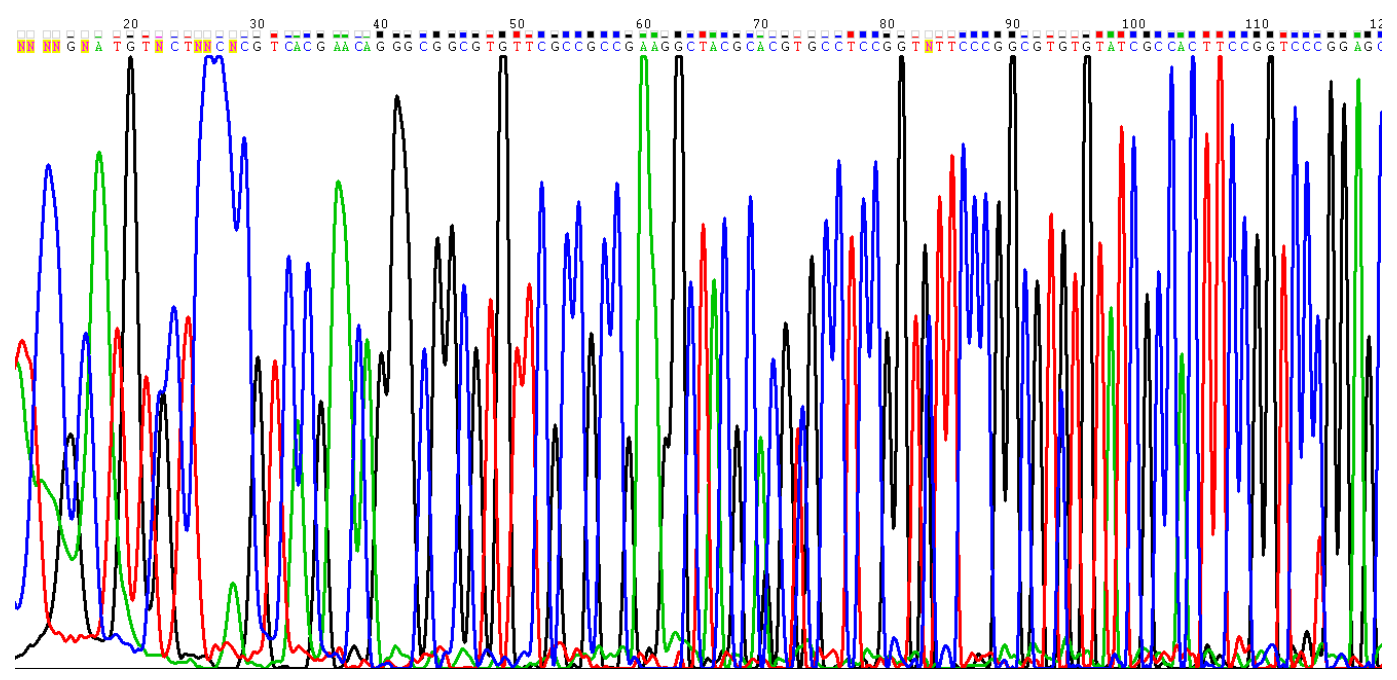

Figure 1: Chromatogram from repeated sequencing of the region of the ALS gene in weedy sunflower DNA. 
on comparison with sequences of the amplified region of ALS gene located in GenBank using a multiple sequence alignment program Clustal Omega.

Note: Several sequences obtained from Source Bioscience were not readable.

Therefore, it was necessary to repeat sequencing (Figure 1).

\subsection{Multiplex PCR-based analysis of microsatellites in three weedy sunflower populations}

Multiplex PCR-based analysis of microsatellites is suitable for studies population variability of weeds. Namely, variation in satellite DNA sequences (different size repeated DNA sequences) can be used to determine genetic differences between organisms or closely related individuals (e.g. weedy sunflower which is result of hybridization between different sunflower forms including crop plant, off-type plants, wild plants, volunteer plants and weedy forms). Satellite loci can be defined by the length of the core repeat, number of repeats or the overall repeat length. Microsatellites are DNA repeats with 2-6 nucleotides in length and they are also called simple sequence repeats (SSRs) or short tandem repeats (STRs).

\subsubsection{Plant material}

Seeds of three different population of weedy sunflower were collected and sown in the greenhouse. Seedlings were transplanted into larger pots. Fresh leaf material from 10 randomly selected plants from each population was collected for DNA extraction. Some leaf samples (taken from a single plant) were used for DNA extraction immediately after sampling, while some them stored in a freezer $\left(-20^{\circ} \mathrm{C}\right)$ until analysis. Before analysis samples were lyophilized after storage at the $-80^{\circ} \mathrm{C}$ during $24 \mathrm{~h}$.

\subsubsection{DNA extraction}

DNA was isolated from about $100 \mathrm{mg}$ of fresh plant leaves according to the QiagenDneasy ${ }^{\circledast}$ Plant Mini Kit following the manufacturer's protocol (https:// www.qiagen.com/dz/shop/sample-technologies/dna/dna-preparation/dneasyplant-mini-kit/). The quality and concentration of extracted DNA were determined spectrophotometrically using a Nanodrop ${ }^{\star} 1000$. DNA extracts were stored at $-20^{\circ} \mathrm{C}$ when not in use.

Note: Yield of DNA from lyophilized samples was low and curve on Nanodrop $^{\circledast} 1000$ was unacceptable. Possible reason was high concentration of proteins. To avoid that, we tried to add polyvinylpyrrolidone (PVP), but the problem persisted. Extraction was repeated using fresh leaf samples and satisfactory yield of DNA was obtained. 


\subsubsection{Primers selection}

Seven microsatellite loci were selected from Garayalde et al. (2011) and Muller et al. (2010). The SSR flouorescently labelled markers were sorted by allelelength range (Table 1 ).

\begin{tabular}{|c|l|l|l|}
\hline $\begin{array}{c}\text { Marker } \\
\text { Name }\end{array}$ & \multicolumn{1}{|c|}{ Forward primer sequence } & \multicolumn{1}{c|}{ Reverse primer sequence } & $\begin{array}{c}\text { Allele size } \\
\text { range }\end{array}$ \\
\hline ORS297 & FAM-GTGTCTGCACGAACTGTGGT & TGCAAAGCTCACACTAACCTG & $214-237$ \\
\hline ORS309 & FAM-CATTTGGATGGAGCCACTTT & GATGAAGATGGGGAATTTGTG & $116-130$ \\
\hline ORS337 & FAM-TTGGTTCATTCATCCTTGGTC & GGGTTGGTGGTTAATTCGTC & $165-197$ \\
\hline ORS342 & NED-TGTTCATCAGGTTTGTCTCCA & CACCAGCATAGCCATTCAAA & $305-361$ \\
\hline ORS371 & HEX-GGTGCCTTCTCTTCCTTGTG & CACACCACCAAACATCAACC & $234-264$ \\
\hline ORS432 & HEX-TGGACCAGTCGTAATCTTTGC & AAACGCATGCAAATGAGGAT & $155-167$ \\
\hline ORS656 & NED-TCGTGGTAAGGGAAGACAACA & ACGGACGTAGAGTGGTGGAG & $181-254$ \\
\hline
\end{tabular}

Table 1: Microsatellite loci, fluorescent dye, sequence, allele size range for 7 SSR markers.

The amplification reaction were examined for each primer separately consisted of $0.1 \mu \mathrm{l}$ of reverse primer and $0.1 \mu \mathrm{l}$ of forward primer, flouorescently labelled with NED, HEX or FAM, $5 \mu \mathrm{l}$ MMx2 (Taq), $3.8 \mu \mathrm{l}$ Rnase-free water and $1 \mu \mathrm{l}$ template DNA in a total volume of $10 \mu \mathrm{l}$. Also, the actual amplification reaction for 7 primer together consisted of each unlabelled reserve primer ( 7 $\times 0.1 \mu \mathrm{l})$ and each of forward primer $(7 \times 0.1 \mu \mathrm{l}), 5 \mu \mathrm{l} \mathrm{MM} \times 2(\mathrm{Taq}), 2.6 \mu \mathrm{l} \mathrm{H}_{2} \mathrm{O}$ and $1 \mu \mathrm{l}$ template DNA a total volume of $10 \mu \mathrm{l}$.

\subsubsection{PCR analysis}

PCR was done following the manufacturer's protocol Type-it ${ }^{\oplus}$ Microsatellite PCR Handbook (https://www.qiagen.com/dz/resources/search-resources).

Thermal Cycler (Applied Byosistems Verite 95 Well) was programmed for initial denaturation step of $94^{\circ} \mathrm{C}$ for $5 \mathrm{~min}$, followed by 6 touchdown cycles of $94^{\circ} \mathrm{C}$ for $30 \mathrm{~s}$, touchdown annealing temperature (Tx) for $90 \mathrm{~s}$ ( Tx is initially $63^{\circ} \mathrm{C}$ and decreases of $1^{\circ} \mathrm{C}$ per cycle for the six first cycles, until it reaches $57^{\circ} \mathrm{C}$ ) and $72^{\circ} \mathrm{C}$ for $60 \mathrm{~s}$. PCR products were subsequently amplified for 29 cycles at $94^{\circ} \mathrm{C}$ for $30 \mathrm{~s}$, touchdown annealing temperature $57^{\circ} \mathrm{C}$ for $90 \mathrm{~s}$ and $72^{\circ} \mathrm{C}$ for $60 \mathrm{~s}$ with a final extension at $63^{\circ} \mathrm{C}$ for $30 \mathrm{~min}$. DNA Fragment Analysis by the Capillary Electrophoresis system is done in Source Bioscience (Nottingham, UK).

\section{Data analysis}

GENEMAPPER (Applied biosystem) and PEAK SCANNER software were used for analyses of the DNA fragments and to score the genotypes (Figure 2). 


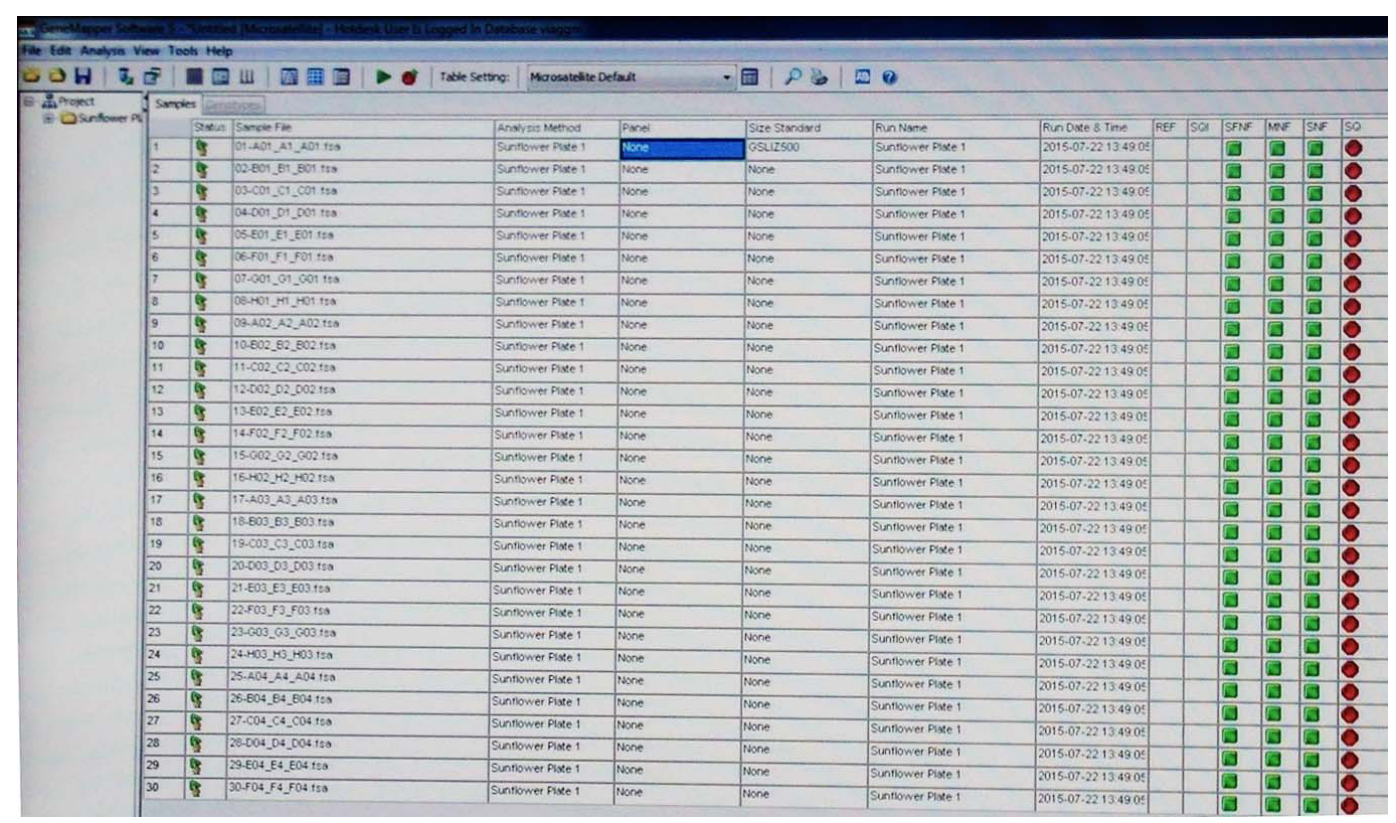

Figure 2: Analyses of the DNA fragments using GENEMAPPER.

\section{Acknowledgements}

This work was funded by EU Commission project AREA, no. 316004. Authors wish to acknowledge prof. Radmila Stikić who has enabled them to train for molecular research and Dr George Gibbins, senior laboratory technician, for realization of training in School of Agriculture, Policy and Development at University of Reading. Also, we thank Dr TijanaBlanuša for support regarding training realization.

\section{References}

Garayalde, A.F., Poverene, M., Cantamutto, M. \& Carrera, A.D. (2011). Wild sunflower diversity in Argentina revealed by ISSR and SSR markers: an approach for conservation and breeding. Annals of Applied Biology, 158, 305-317. DOI: https://doi.org/10.1111/j.1744-7348.2011.00465.x

Gaskin, J. F., Bon, M. C., Cock, M. J., Cristofaro, M., De Biase, A., De ClerckFloate, R., Ellison, C.A., Hinz, H.L., Hufbauer, R.A., Julien, M.H. \& Sforza, R. (2011). Applying molecular-based approaches to classical biological control of weeds. Biological Control, 58, 1-21. DOI: https://doi.org/10.1016/j. biocontrol.2011.03.015

Goolsby, J.A., De Barro, P.J., Makinson, J.R., Pemberton, R.W., Hartley, D.M., \& Frohlich, D.R. (2006). Matching the origin of an invasive weed for selection 
of a herbivore haplotype for a biological control programme. Molecular Ecology, 15, 287-297. DOI: https://doi.org/10.1111/j.1365-294X.2005.02788.x NBS Biologicals. (2015). Spin Column Purification DNA Cleanup Handbook. Retrieved from http://www.nbsbio.co.uk/downloads/DNA_Cleanup_Handbook. pdf

Qiagen. (2015). DNeasy ${ }^{\circledast}$ Plant Handbook. Retrieved from https://www.qiagen. $\mathrm{com} / \mathrm{dz} /$ shop/sample-technologies/dna/dna-preparation/dneasy-plantmini-kit/

Qiagen. (2009). Type-it ${ }^{\oplus}$ Microsatellite PCR Handbook. Retrieved from https:// www.qiagen.com/dz/resources/search-resources.

Kolkman, J.M., Slabaugh, M.B., Bruniard, J.M., Berry, S., Bushman, B.S., Olungu, C., Maes, N., Abratti, G., Zambelli, A., Miller, J.F., Leon, A. \& Knapp, S.J. (2004). Acetohydroxyacid synthase mutations conferring resistance to imidazolinone or sulfonylurea herbicides in sunflower. Theoretical and Applied Genetics, 109, 1147-1159. DOI: https://doi.org/10.1007/ s00122-004-1716-7

Madeira, P.T., Coetzee, J.A., Center, T.D., White, E.E. \& Tipping, P.W. (2007). The origin of Hydrillaverticillata recently discovered at a South African dam. Aquatic Botany, 87, 176-180. DOI: https://doi.org/10.1016/j. aquabot.2007.04.008

Michitte, P., De Prado, R., Espinoza, N., Ruiz-Santaella, J.P. \& Gauvrit, C. (2007). Mechanism of Resistance to glyphosate in Ryegrass (Lolium multiflorum) Biotype from Chile. Weed Science, 55, 435-440. DOI: http://dx.doi. org/10.1614/WS-06-167.1

Moss, S.R., Perryman, S.A.M. \& Tatnell, L.V. (2007). Managing HerbicideResistant Blackgrass (Alopecurus myosuroides): Theory and Practice. Weed Technology, 21, 300-309. DOI: https://doi.org/10.1614/WT-06-087.1

Muller, M-H., Latreille, M. \& Tollon, C. (2010). The origin and evolution of a recent agricultural weed: population genetic diversity of weedy population od sunflower (Helianthus annuus L.) in Spain and France. Evolutionary application, Blackwell, 4, 499-514. DOI: https://doi.org/10.1111/j.17524571.2010.00163.x

Paterson, I. D., Douglas A. D. \& Hill, M. P. (2009). Using molecular methods to determine the origin of weed populations of Pereskia aculeata in South Africa and its relevance to biological control. Biological Control, 48, 84-91. DOI: https://doi.org/10.1016/j.biocontrol.2008.09.012

Slotta T.A.B., Rothhouse J.M., Horvath D.P. \& Foley M.E. (2006). Genetic diversity of Canada thistle (Cirsium arvense) in North Dakota. Weed Science 54, 1080-1085. DOI: http://dx.doi.org/10.1614/WS-06-038R1.1

White, A.D., Graham, M.A. \& Owen, M.D.K. (2003). Isolation of acetolactate synthase homologs in common sunflower. Weed Science, 51, 845-853. DOI: https://doi.org/10.1614/P2002-136 